\title{
A Comprehensive Review and the Efficiency Analysis of Horizontal and Vertical Axis Wind Turbines
}

\author{
Saad Bin Abul Kashem ${ }^{1 *}$, Muhammad E. H. Chowdhury ${ }^{2}$, Molla Ehsanul Majid ${ }^{3}$, Azad Ashraf ${ }^{4}$, \\ Mazhar Hasan-Zia ${ }^{4}$, Mohammad Nashbat ${ }^{4}$, Aliyaru Kunju ${ }^{4}$, Amin Esmaeili ${ }^{4}$
}

\footnotetext{
${ }^{1}$ Department of Computer Science and Engineering, College of Engineering, Qatar University, Doha 2713, QATAR

${ }^{2}$ Department of Electrical Engineering, College of Engineering, Qatar University, Doha 2713, QATAR

${ }^{3}$ Computing faculty, Academic Bridge Program, Qatar Foundation, Doha, QATAR

${ }^{4}$ Department of Chemical Engineering and Process Technology, College of North Atlantic, QATAR

*Corresponding Author: saadaip@gmail.com
}

Citation: Kashem, S. B. A., Chowdhury, M. E. H., Majid, M. E., Ashraf, A., Hasan-Zia, M., Nashbat, M., Kunju, A. and Esmaeili, A. (2021). A Comprehensive Review and the Efficiency Analysis of Horizontal and Vertical Axis Wind Turbines. European Journal of Sustainable Development Research, 5(3), em0163. https://doi.org/10.21601/ejosdr/11001

\section{ARTICLE INFO}

Received: 28 Jan. 2021

Accepted: 2 Apr. 2021

\begin{abstract}
The Wind has the potential as an alternative source of renewable energy. Natural wind from the earth's atmosphere is captured before converted into mechanical energy and then electrical energy. This paper presents a comparison of the efficiency of the horizontal axis wind turbine (HAWT) and vertical axis wind turbines (VAWT). The efficiency is determined using SOLIDWORKS Flow Simulation considering the wind scenario, a constant wind speed of $5 \mathrm{~km} / \mathrm{h}$ with constant wind direction. It has been found that the drag coeffiecient of HAWT, VAWT-Savonius and VAWT- Darrieus are $0.5175,0.2605$ and 13.5622 respectively. This paper also proposes building a wind farm in Seamatan where the average wind speed is highest in Sarawak, Malaysia ranging from $4 \mathrm{~km} / \mathrm{h}$ to $9 \mathrm{~km} / \mathrm{h}$.
\end{abstract}

Keywords: horizontal axis wind turbine, vertical axis wind turbine, efficiency comparison, renewable energy, green energy

\section{INTRODUCTION}

Historically, as early as 5000 B.C., wind energy was used to propel boats (4C Offshore, 2013a). By 200 B.C., windmill in China was used for water pump purposes, while in Persia and the Middle East vertical-axis windmills used to grind grain (4C Offshore, 2013b). The windmills technology was further developed, the usage of the technology was widening into the agricultural industry, transportation, and food productions. European and American colonists used windmills to pump water for farms, grind corn and wheat, and cut wood. In the nineteenth and early twentieth centuries, the windmill was developed for generating electrical energy. Small scale wind plants are used to power farms and residences, while largescale plants used to generate electricity for industry. During World War II, a 1.25-megawatt wind turbine was made in Denmark known as the Grandpa's Knob, purposely to fulfil the electricity demanded from the industry and homes (Aeolos Wind Energy Ltd., 2016; AWEC, 2015; Belarusian web portal on renewable energy, 2012; Charles, 2014; Clean Green Renewable Energy, 2016; David, 2010; GWEC, 2015). However, due to the availability of cheap oil in the market during the time, has suspended the usage of the wind turbine as the main source of energy. Following the OPEC Oil Embargo in 1973, as the oil prices change and continue to increase due to the demands, wind energy seems to gain its popularity again (IEC, 2016). Government policies and the increasing awareness of the effects of oil usage on health and the environment helped the growth trends of wind energy. In the late 1970s, the wind industry had gained solid markets, with almost 50 manufacturers of wind turbines (IEC, 2016). In the 1980s, the wind farm was introduced in the market to reduce the cost of independent wind plants and increase production efficiency (IEC, 2016; Karen, 2012; Merle et al., 2016; Paul, 2012). The cost of installing wind power plants continuously decreased, which promoted wider usage of wind energy.

According to Rao and Gantayat (2010), the global wind energy industry had the largest average growth in the renewable energy sector about $27 \%$ within the years of 2004 to 2009. Asia is the biggest wind energy harvester with about $41 \%$ of the world's total wind turbine number, as China controls the wind industry market (GWEC, 2015; Rigzone, 2016). The ranking is followed by Europe, with a production of about 34\% of energy. Europe generates about $76152 \mathrm{MW}$ in 2009, and the number is continuously growing. In the US alone, AWEC 


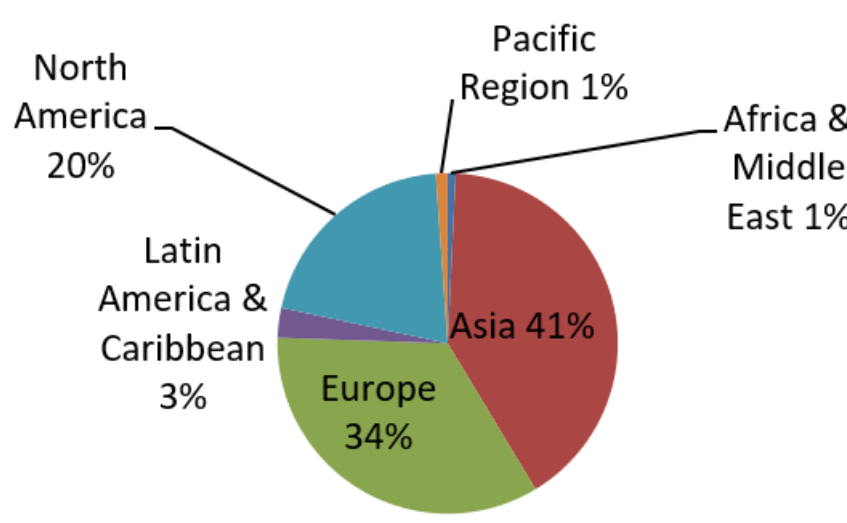

Figure 1 . The percentage of the usage wind turbine by regional distributions

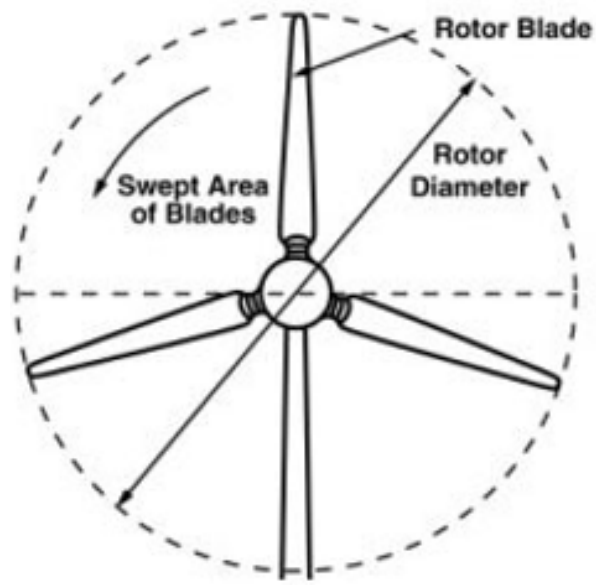

Figure 2. The swept area of the horizontal axis wind turbine (Clean Green Renewable Energy, 2016)

(2015) reported that wind turbine technology is capable of providing about 19 million houses with low-cost electricity usage. The usage of a wind turbine in the Pacific, Africa, Middle East, Latin America, and the Caribbean is started to grow. The high availability and affordable price boost the growth among these regions. Figure $\mathbf{1}$ is derived from GWEC (2015), shows the percentage of the global wind turbine applications by region.

The wind turbine is categorized into two main types:

1) Horizontal axis wind turbine (HAWT): The wind turbine rotational axis is parallel to the wind stream and ground. The rotor, generator, and gearbox are installed at the back of the blades.

2) Vertical axis wind turbine (VAWT): The turbine rotational axis is perpendicular to the ground. The rotor, generator, and gearbox are located on the base.

\section{LITERATURE REVIEW}

The swept area of a wind turbine is determined by the rotor blade where the swept area of the horizontal axis wind turbine is the front plane of the rotor blades, where it is given as:

$$
A=\pi R^{2}
$$

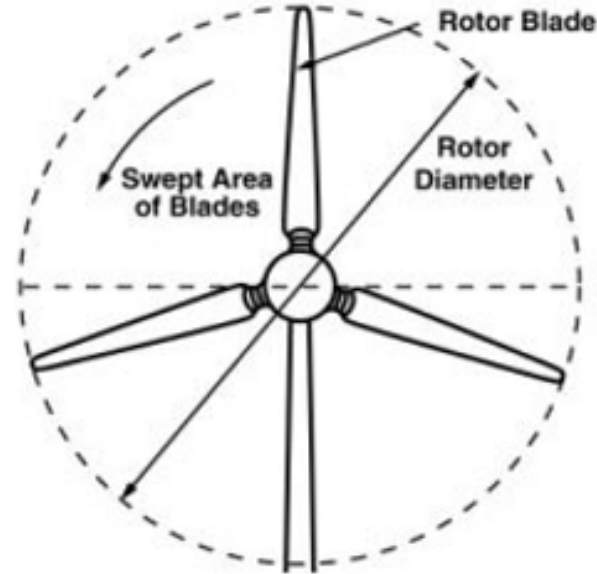

Figure 3. The swept area of the Savonius vertical axis wind turbine (Belarusian web portal on renewable energy, 2012)

The swept area of Darrieus vertical axis wind turbine is the plane parallel to the ground, where it is given as:

$$
A=0.65 D H
$$

The Savonius vertical axis wind turbine has the same operation as the Darrieus vertical axis wind turbine, and its swept area is given as:

$$
A=D H
$$

The swept area of a vertical axis wind turbine is typically twice the swept area of the horizontal axis wind turbine (Clean Green Renewable Energy, 2016; Paul, 2012).

Three-blade wind turbines are commonly used in the market. The number of blades directly relates to the efficiency of the wind turbine due to the wind turbine has a high frequency to extract wind power. The common numbers of blades are 2, 3, and 5 . The greater number of blades improves the reliability and safety of the wind turbine (Clean Green Renewable Energy, 2016; turbinesinfo, 2011; Wang and Fan, 20115; WEF, 2016; Wind Energy - The Facts, 2009; Windpower Engineering, 2011).

The cost of a two-blade wind turbine is slightly lower than that of the three-blade wind turbine. A two-blade wind turbine spins fast, but in return, it produces a higher level of noise compared to the noise pollution of the three-blade wind turbine. The three-blade standard makes the wind turbine spinning more smoothly and reduces the damage to the bearing.

Lift and drag forces are produced by the differential pressure based on Bernoulli's principle. Drag force has the same direction as that of the flow against the front side of the blades. Either one or both of these forces is needed to rotate the blades of a wind turbine. The lift and drag forces on a blade also involve the coefficient lift, $C_{L}$, the coefficient of drag, $C_{D}$, the density of air, $\rho$, wind speed, $v$, the length of the blade, $b$, and the chord length, $c$.

The wind turbine has fixed conversion efficiency for converting wind energy into electrical energy. The conversion efficiency is called power efficiency, $C_{P}$ whereof the actual electrical output power over the input power or the available wind energy. These formulae can be expressed as: 


$$
\begin{gathered}
C_{P}=\frac{P_{\text {out }}}{P_{\text {in }}} \\
P_{\text {out }}=0.5 C_{P} \rho A v^{3}
\end{gathered}
$$

$C_{P}$ can be further differentiated into turbine efficiency, $\eta_{t}$, mechanical efficiency, $\eta_{m}$ and electrical efficiency, $\eta_{e}$.

Turbine efficiency is also called aerodynamic efficiency. The kinetic energy loss occurs during the conversion of kinetic energy into mechanical energy of the turbine shaft, which contributes to the efficiency reduction.

Mechanical efficiency involves energy losses in bearing and gear tooth friction. The shaft support bearings contribute a little friction to the shafts. The energy losses turn out to be heat and noise during energy transfer. Electrical efficiency involves power losses to windage, bearings, and electrical resistance (David, 2010).

Rotor blades are mostly made of carbon fiber to take advantage of its properties - lightweight, low density, and high stiffness, and the alternative materials that can be considered for small wind turbines are aluminum and fiberglass due to heavyweight and then leads to material fatigue (World Wind Energy Association, 2014). Karen (2012) stated carbon fiber has proven to be an enabling technology for the turbine. The wind turbine tower and other components are made of steel. The wire and cable used are copper-clad steel to be more reliable and cost-effective (Malaysian Department of Statistics, 2010; Windpower Engineering, 2011).

The angle of attack, also called pitch, is calculated using wind speed, rotating blade velocity, and pitch angle, $\beta$ as follows:

$$
\begin{gathered}
v_{r}=\sqrt{v_{\infty}^{2}+(\omega R)^{2}} \\
\alpha=\sin ^{-1}\left(v_{\infty} / v_{r}\right)-\beta
\end{gathered}
$$

The angle of attack results in the coefficients of lift and drag. The coefficients of lift and drag can then be calculated using:

$$
\begin{aligned}
& C_{L}=C_{N} \cos \alpha+C_{T} \sin \alpha \\
& C_{D}=C_{N} \sin \alpha-C_{T} \cos \alpha
\end{aligned}
$$

The coefficients of thrust and torque can then be determined using:

$$
\begin{aligned}
& C_{\text {thrust }}=C_{L} \cos (\alpha+\beta)+C_{D} \sin (\alpha+\beta) \\
& C_{\text {torque }}=C_{L} \sin (\alpha+\beta)-C_{D} \cos (\alpha+\beta)
\end{aligned}
$$

(Merle et al., 2016).

The chord length of a blade is defined as the distance between the leading edge and trailing edge. The chord length of a blade contributes torque and thrust, and the formulae are as follows:

$$
\begin{gathered}
F_{\text {thrust }}=0.5 C_{\text {thrust }} \rho v^{2} c \\
F_{\text {torque }}=0.5 C_{\text {torque }} \rho v^{2} c \\
T=F_{\text {torque }} R
\end{gathered}
$$

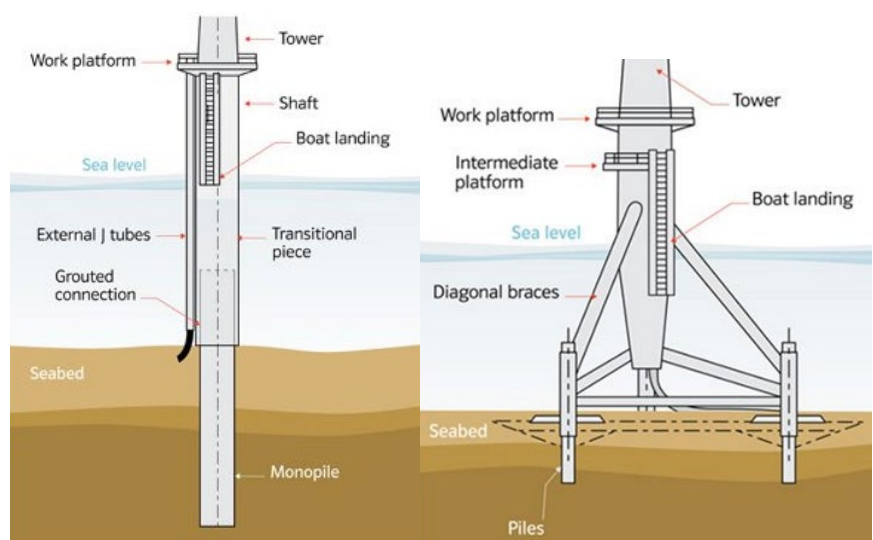

Figure 4. The monopile and tripod foundation (4C Offshore, 2013a)

(Merle et al., 2016).

Foundations used on offshore wind projects today are monopile, gravity foundation, tripod foundation, and tension leg platform. Monopile foundation is made of either concrete or steel which is driven approximately 10 meters to 20 meters into the seabed and depending on soil condition, and it is suitable for water depth up to 30 meters. Similarly, the tripod foundation consists of steel tripod and concrete piles, and it is suitable for a range of water depths from 25 meters to 40 meters. Energy generation from solar (Ahmed et al., 2017, 2019; Ashraf et al., 2021; Chowdhury and Kashem, 2018; Hong et al., 2018; Karuppasamy et al., 2020; Kashem et al., 2020a; Kho et al., 2017; Mubarak and Kashem, 2016; Sheikh et al., 2017; Tabassum et al., 2017; Touati et al., 2020), wind (Kashem et al., 2020b; Khandakar and Kashem, 2020; Safe et al., 2014), and biomass (Kashem et al., 2020c, 2020d, 2020e; Siddique et al., 2017, 2018) have advantages and disadvantages. Similarly, Hydropower has pros and cons (Azmi et al., 2017; Kashem et al., 2018a, 2020f). The proper way of energy distribution and considering economic and environmental impact may mitigate the drawbacks (Kashem et al., 2018b, 2021a; Tabassum et al., 2016, 2018). Moreover, people can use less energy through green buildings (Che Hamzah et al., 2020; Kashem et al., 2021b; Shabrin and Kashem, 2017; Shabrin et al., 2017). According to researchers, wind energy is still the best way to harness renewable energy.

A gravity foundation is a large base constructed on the seabed that is made of either concrete or steel to allow the wind turbine remains erect.

The tension leg platform consists of piles driven into the seabed, tension legs to secure the wind turbine, and buoyant hull supports. The mooring tension leg platform allows horizontal movement due to wave disturbances but does not allow vertical movement. Wang and Fan (2015) stated tension leg platform is cost-effective when the water depth reaches 50 meters.

Sematan is a fishing village where approximately 67.5 kilometres away from the state capital Kuching with a population of 7602 (Malaysian Department of Statistics, 2010). The energy usage over a year in Sematan is Figure 7. The availability of wind energy in Sematan is studied through weather information (Climate History for Kuching, 2016). 


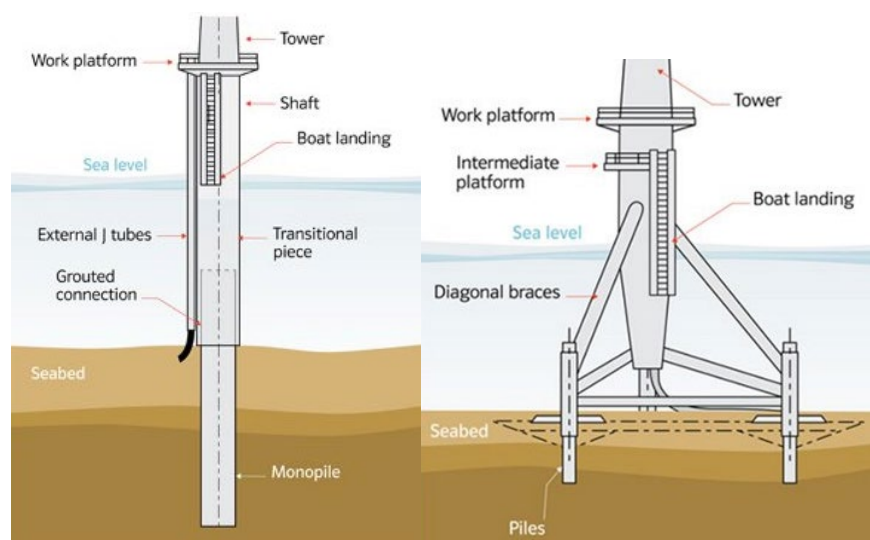

Figure 5. The gravity foundation (Wind Energy - The Facts, 2009)

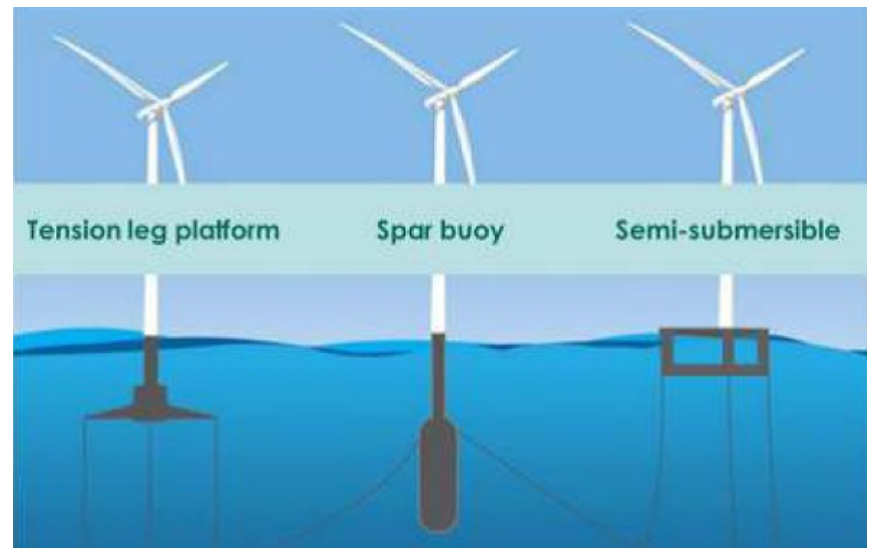

Figure 6. The types of tension leg platforms (Charles, 2014)

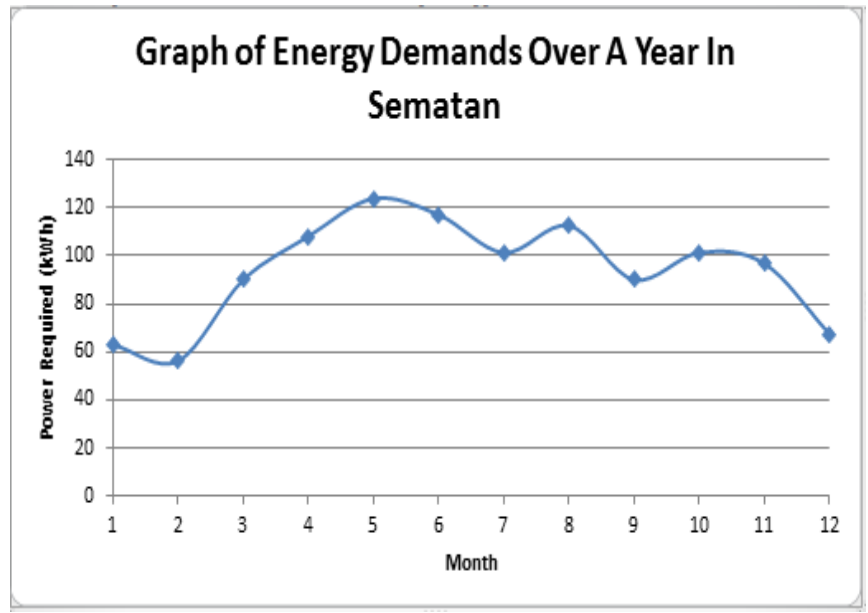

Figure 7. The graph of energy demands over a year in Sematan

\section{RESULTS OF PERFORMANCE ANALYSIS OF HAWT AND VAWT}

Inflow simulation of the turbines, several parameters have been considered. The wind flow at the velocity of $1.389 \mathrm{~m} / \mathrm{s}$ or $5 \mathrm{~km} / \mathrm{h}$ from one direction and $1.225 \mathrm{~kg} / \mathrm{m}^{3}$ of air density have been used. The performance analysis for each turbine is evaluated based on its pressure and velocity generated.

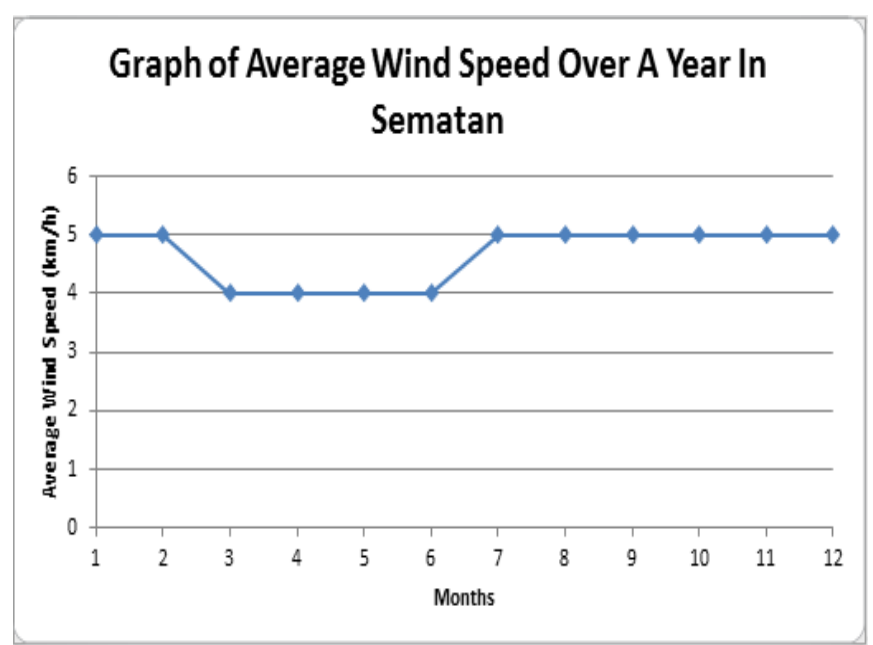

Figure 8. The graph of the average wind speed over a year in Sematan

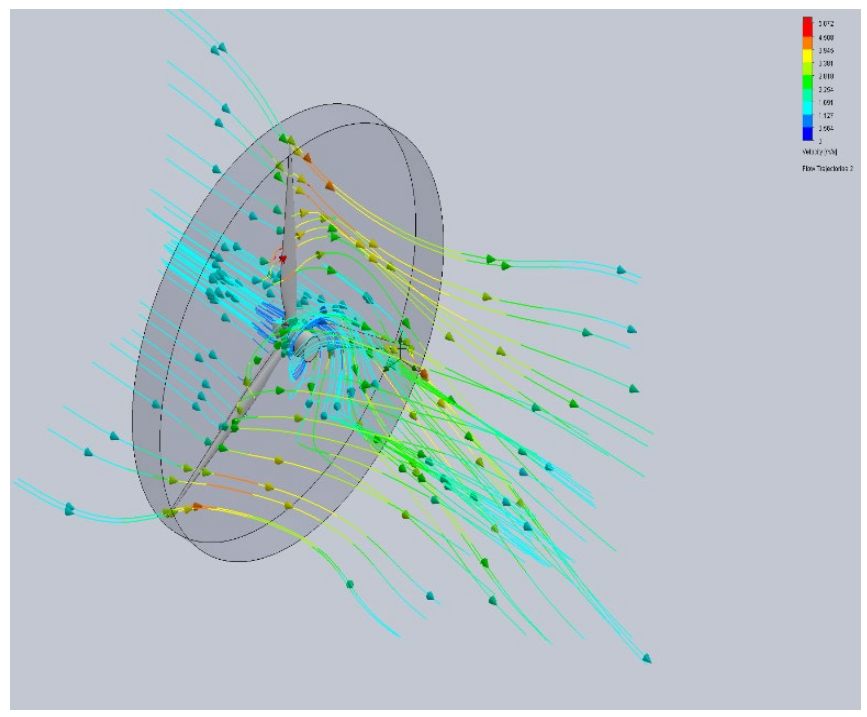

Figure 9. The velocity analysis of HAWT

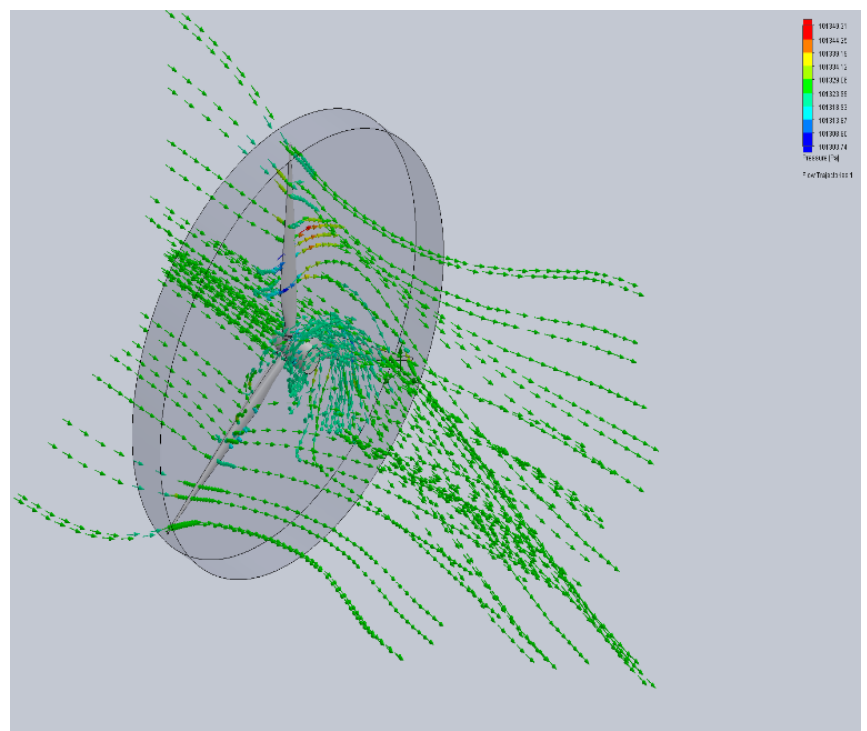

Figure 10. The pressure analysis of HAWT

Figures 9 to 14 show the velocity and pressure analysis for HAWT and VAWT. 


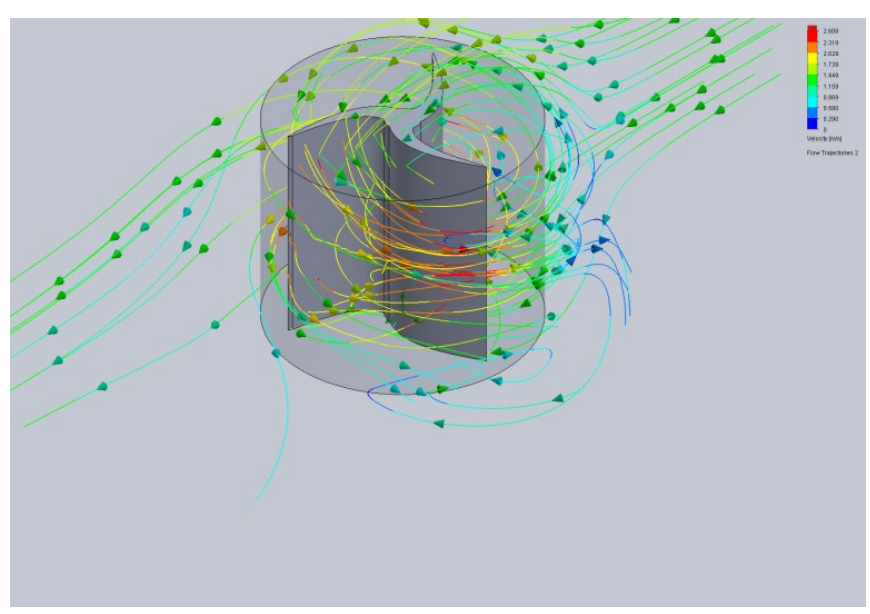

Figure 11. The velocity analysis of the Savonius wind turbine

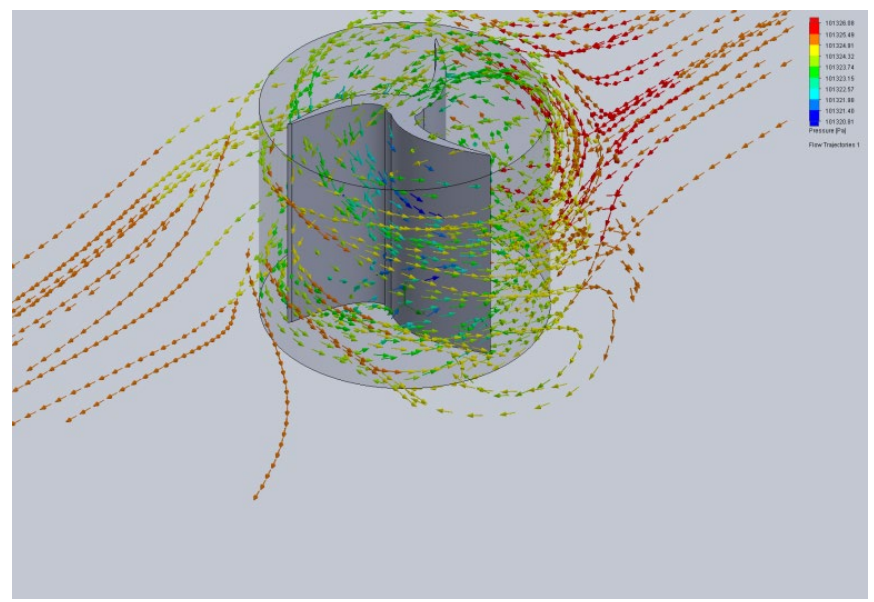

Figure 12. The pressure analysis of the Savonius wind turbine

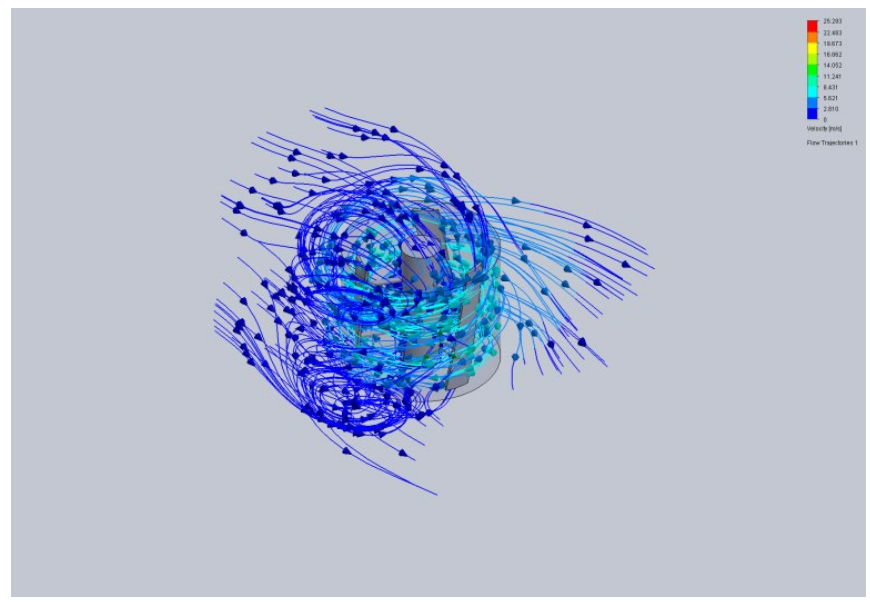

Figure 13. The velocity analysis of the Darrieus wind turbine

\section{Horizontal Axis Wind Turbine (HAWT)}

The dimension of HAWT is $10 \mathrm{~m}$ diameter by $1 \mathrm{~m}$ depth. The swept area covered by HAWT is $78.53 \mathrm{~m}^{2}$.

\section{Vertical Axis Wind Turbine (VAWT)}

\section{Savonius wind turbine}

The dimensions of VAWT, Savonius wind turbine is $1 \mathrm{~m}$ diameter by $1 \mathrm{~m}$ height. The swept area covered is $1 \mathrm{~m}^{2}$.

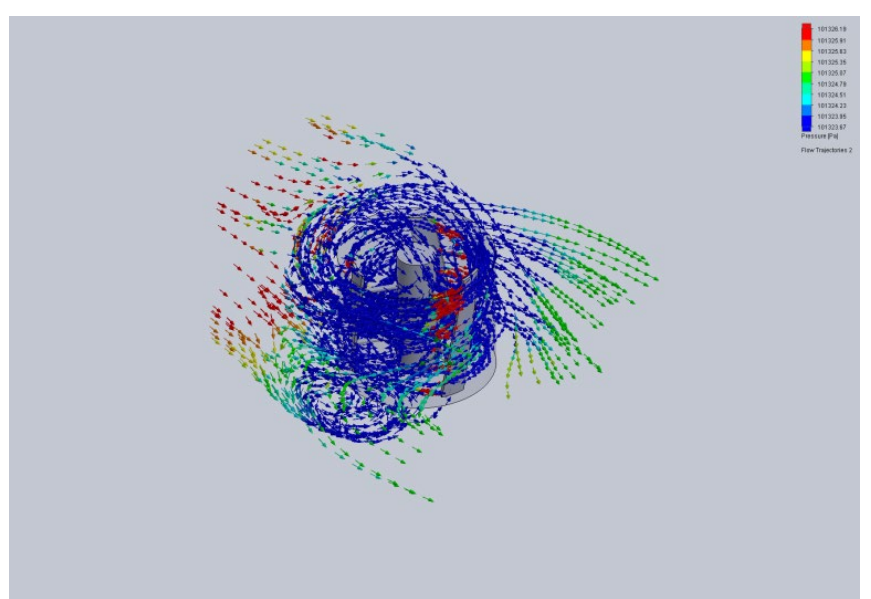

Figure 14. The pressure analysis of the Darrieus wind turbine

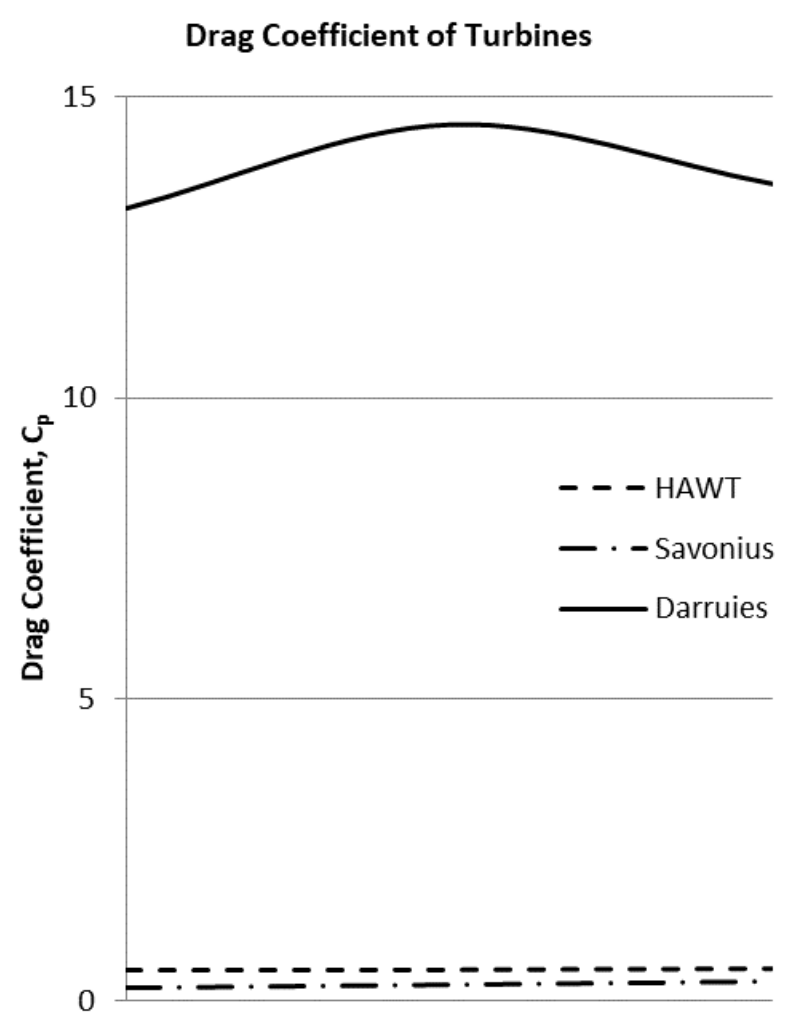

Figure 15. The comparison of the drag coefficient of each turbine

\section{Darrieus wind turbine}

The dimensions of VAWT, Savonius wind turbine is $1 \mathrm{~m}$ diameter by $1 \mathrm{~m}$ height. The swept area covered is $0.65 \mathrm{~m}^{2}$.

\section{DISCUSSION OF PERFORMANCE ANALYSIS OF HAWT AND VAWT}

From Tables 1-3, it has been found that the maximum and average velocity of VAWT- Darrieus shows a higher drag coefficient compared to HAWT and VAWT-Savonius. The maximum pressure of HAWT shows a higher drag coefficient compared to VAWT- Darrieus and VAWT-Savonius. However, average drag force of VAWT- Darrieus shows a higher drag 
Table 1. Performance analysis of HAWT

\begin{tabular}{cccc}
\hline & Minimum & Maximum & Average \\
\hline Velocity $(\mathbf{m} / \mathbf{s})$ & 0 & 5.072 & 2.536 \\
\hline Pressure $(\mathbf{P a})$ & 101303.74 & 101349.31 & 101326.52 \\
\hline Drag force $(\mathbf{N})$ & 0.5985 & 0.6407 & 0.6116 \\
\hline
\end{tabular}

Table 2. Performance analysis of VAWT - Savonius Types

\begin{tabular}{cccc}
\hline & Minimum & Maximum & Average \\
\hline Velocity (m/s) & 0 & 2.608 & 1.304 \\
\hline Pressure (Pa) & 101320.81 & 101326.08 & 101323.445 \\
\hline Drag force (N) & 0.247805 & 0.368880 & 0.30785 \\
\hline
\end{tabular}

Table 3. Performance analysis of VAWT - Darrieus Types

\begin{tabular}{cccc}
\hline & Minimum & Maximum & Average \\
\hline Velocity (m/s) & 0 & 5.621 & 2.8105 \\
\hline Pressure (Pa) & 101323.71 & 101326.19 & 101324.95 \\
\hline Drag force (N) & 15.54959 & 17.17494 & 16.026627 \\
\hline
\end{tabular}

Table 4. Drag Coefficient Analysis of Turbines

\begin{tabular}{cccc}
\hline Drag Coefficient, $\left(\mathbf{C}_{\mathbf{p}}\right)$ & Minimum & Maximum & Average \\
\hline HAWT & 0.5064 & 0.5421 & 0.5175 \\
\hline VAWT-Savonius & 0.2097 & 0.3121 & 0.2605 \\
\hline VAWT- Darrieus & 13.1586 & 14.5330 & 13.5622 \\
\hline
\end{tabular}

coefficient compared to HAWT and VAWT-Savonius. The drag coefficient of the turbine can be further calculated from the value of drag force using equation (5) which is depicted at Table 4. According to equation (5) the value of $\mathrm{Cp}$ could be increased corresponding the value of the velocity.

\section{CONCLUSION \& FUTURE WORK}

To conclude, it is well known that HAWT has better output power performance than VAWT in normal condition. However, Darrieus of VAWT shows a higher drag coefficient compared to HAWT and VAWT-Savonius. This paper includes the comparison of the turbines in terms of maximum and minimum Velocity $(\mathrm{m} / \mathrm{s})$, Pressure $(\mathrm{Pa})$, Drag force $(\mathrm{N})$ and Drag Coefficient, (Cp). The mesh independency, energy analysis, optimization and CFD analysis will be included in future work. Since Sematan is a fishing remote village in Sarawak, Malaysia and population is only 7602, a wind firm can support their electricity need efficiently. Therefore, this paper proposes building a wind farm in Seamatan to support the community. The average wind speed in Sematan is highest in Sarawak, Malaysia ranging from $4 \mathrm{~km} / \mathrm{h}$ to $9 \mathrm{~km} / \mathrm{h}$. Hence, in the Sematan profile, the most suitable turbine is VAWT Darrius as it provides better performance.

Author contributions: All co-authors have involved in all stages of this study while preparing the final version. They all agree with the results and conclusions.

Funding: No external funding is received for this article.

Declaration of interest: The authors declare that they have no competing interests.

Ethics approval and consent to participate: Not applicable.

Availability of data and materials: All data generated or analyzed during this study are available for sharing when appropriate request is directed to corresponding author.

\section{REFERENCES}

4C Offshore. (2013a). Monopiles support structures. Available at: http://www.4coffshore.com/windfarms/monopilessupport-structures-aid4.html

4C Offshore. (2013b). Tripod support structures. Available at: http://www.4coffshore.com/windfarms/tripod-supportstructures-aid7.html

Aeolos Wind Energy Ltd. (2016). Horizontal axis wind turbine vs. vertical axis wind turbine. Available at: http://www.windturbinestar.com/hawt-vs-vawt.html

Ahmed, J., Nabipour-Afrouzi, H., Naim, M. F. and Tajuddin, Kashem, S. B. A. (2019). Modified series-parallel photovoltaic configuration to enhance efficiency under partial shading. International Journal of Integrated Engineering, 11(3), 207-215. https://doi.org/10.30880/ ijie.2019.11.03.021

Ahmed, J., Salam, Z., Then, Y. L. and Kashem, S. B. A. (2017). A fast MPPT technique based on IV curve characteristics under partial shading. In Region 10 Conference, TENCON IEEE (pp. 1696-1701). IEEE. https://doi.org/10.1109/ TENCON.2017.8228132

Ashraf, A., Odud, M. Majid, M. Kashem, S. B. K. and Chowdhury, M. E. H. (2021). Designing a solar-powered shower room at Damai Beach, Kuching, Malaysia. International Journal of Technology, 2(1), 35-53.

AWEC. (2015). 2015 US wind industry market reports (1st ed.). Available at: http://www.awea.org/Resources/Content. aspx?ItemNumber=7525\&RDtoken=29653\&userID

Azmi, F., Kashem, S. B. A. and Shaila, S. (2017). A comprehensive analysis of rack and rake wheel turbine. International Conference on Engineering and Natural Science, Bali, Indonesia, 4, 1-12.

Belarusian web portal on renewable energy. (2012). Wind energy overview. Available at: http://re.energybel.by/en/ renewable-energy-technologies/wind/\#!prettyPhoto

Charles, R. B. (2014). Floating wind turbine technologies and their associated risks. Wiki Cleantech. Available at: http://wiki-cleantech.com/wind-energy/floating-windturbine-technologies-and-their-associated-risks

Che Hamzah, N. H., Khairuddin, N., Siddique, B. M. and Hassan, M. A. (2020). Potential of Jatropha curcas L. as Biodiesel Feedstock in Malaysia: A Concise Review. Processes, 8(7), 786. https://doi.org/10.3390/pr8070786

Chowdhury, M. A. and Kashem, S. B. A. (2018). H $\infty$ loopshaping controller design for a grid-connected singlephase photovoltaic system. International Journal of Sustainable Engineering, 11(3), 196-204. https://doi.org/ 10.1080/19397038.2018.1444680

Clean Green Renewable Energy. (2016). Wind turbine motor basic calculations. Available at: http://cleangreenenergy zone.com/wind-turbine-permanent-magnet-dc-motors

Climate History for Kuching. (2016). Weather2. Available at: http://www.myweather2.com/City-

Town/Malaysia/Kuching/climate-profile.aspx?month=12 
David, E. W. (2010). Wind turbine power coefficient (Cp). FT Exploring. Available at: http://www.ftexploring.com/windenergy/wind-power-coefficient.htm

GWEC. (2015). Global wind statistics 2015 (1st ed.). Available at: http://www.gwec.net/wp-content/uploads/vip/GWECPRstats-2015_LR_corrected.pdf

Hong, L. T., Ahmed, J., Nabipour-Afrouzi, H. and Kashem, S. (2018, October). Designing a PSCAD based PV simulator for partial shading to validate future PV application planning. In 2018 IEEE PES Asia-Pacific Power and Energy Engineering Conference (APPEEC) (pp. 526-531). IEEE. https://doi.org/10.1109/APPEEC.2018.8566639

IEC. (2016). History of wind energy. Iowa Energy Center. Available at: http://www.iowaenergycenter.org/windenergy-manual/history-of-wind-energy

Karen, W. (2012). Wind turbine blades: Glass vs. carbon fiber. Composites World. Available at: https://www.compositesworld.com/articles/wind-turbineblades-glass-vs-carbon-fiber

Karuppasamy, K., Tabassum, M., Ramamoorthy, A., Sasikala, K. and Kashem, S. B. A. (2020). Prototype design for controlling a solar powered car with a GSM remote control. International Journal of Technology, 1(2), 45-64.

Kashem, S. B. A., Chowdhury, M. E., Ahmed, J., Ashraf, A. and Shabrin, N. (2020a). Wind power integration with smart grid and storage system: Prospects and limitations. International Journal of Advanced Computer Science and Applications, 11(5), 552-569. https://doi.org/10.14569/ IJACSA.2020.0110570

Kashem, S. B. A., Chowdhury, M. E., Khandakar, A., Tabassum, M., Ashraf, A. and Ahmed, J. (2020b). A comprehensive investigation of suitable biomass raw materials and biomass conversion technology in Sarawak, Malaysia. International Journal of Technology, 1(2), 75-105.

Kashem, S. B. A., Chowdhury, M. E., Khandakar, A., Tabassum, M., Ashraf, A. and Ahmed, J. (2020c). An investigation of passive cooling in a building in Malaysia. International Journal of Technology, 1(2), 4-27.

Kashem, S. B. A., Chowdhury, M. E., Tabassum, M., Molla, M. E., Ashraf, A. and Ahmed, J. (2020d). Feasibility Study of Solar Power System in Residential Area. International Journal of Innovation in Computational Science and Engineering, 1(1), 10-17.

Kashem, S. B. A., Chowdhury, M. E., Tabassum, M., Molla, M. E., Ashraf, A. and Khandakar, A. (2020e). A Comprehensive Study on Biomass Power Plant and Comparison Between Sugarcane and Palm Oil Waste. International Journal of Innovation in Computational Science and Engineering, 1(1), 26-32.

Kashem, S. B. A., De Souza, S., Iqbal, A. and Ahmed, J. (2018a). Microgrid in military applications. In IEEE 12th International Conference on Compatibility, Power Electronics and Power Engineering (CPE-POWERENG) (pp. 1-5). IEEE. https://doi.org/10.1109/CPE.2018.8372506

Kashem, S. B. A., Majid, M. E., Tabassum, M., Ashraf, A., Guziński, J. and Łuksza, K. (2020f). A preliminary study and analysis of tidal stream generators. Acta Energetica, (42), 614.
Kashem, S. B. A., Ngambi, D. T., Ahmed, J., Qidwai, U. and Suresh, P. (2021a). Experimental analysis of gravity and buoyancy powered energy generation storage systems. In P. Suresh, U. Saravanakumar and M. Hussein Al Salameh (Eds.), Advances in smart system technologies. Advances in intelligent systems and computing (vol. 1163). Springer, Singapore. https://doi.org/10.1007/978-981-15-5029-4_70

Kashem, S. B. A., Sheikh, M. I. B., Ahmed, J. and Tabassum, M. (2018b). Gravity and buoyancy powered clean water pipe generator. In IEEE 12th International Conference on Compatibility, Power Electronics and Power Engineering (CPE-POWERENG) (pp. 1-5). IEEE.

Kashem, S. B. A., Zia, M., Nashbat, M., Kunju, A., et al. (2021b). A Review and Feasibility Study of Geothermal Energy in Indonesia. International Journal of Technology, 2(1), 19-34.

Khandakar, A. and Kashem, S. B. A. (2020). Feasibility study of Horizontal-Axis Wind Turbine. International Journal of Technology, 1(2), 140-164.

Kho, C. T. K., Ahmed, J., Kashem, S. B. A. and Then, Y. L. (2017). A comprehensive review on PV configurations to maximize power under partial shading. In Region 10 Conference, TENCON IEEE (pp. 763-768). IEEE. https://doi.org/10.1109/TENCON.2017.8227962

Malaysian Department of Statistics. (2010). Population and housing census of Malaysia. Available at: https://www.statistics.gov.my/mycensus2010/images/stor ies/files/Laporan_Kiraan_Permulaan2010.pdf

Merle, C. P., David, C. W. and Bassem, H. R. (2016). Mechanics of Fluids (5th ed.).

Mubarak, H. and Kashem, S. B. A. (2016). Comparison of different energy saving lights using solar panel. Frontiers in Energy, 10(4), 466-472. https://doi.org/10.1007/s11708016-0417-7

Paul, G. (2012). Wind power: Renewable energy for home, farm, and business (2nd ed.). Chelsea Green Publishing, White River Junction, VT.

Rao, K. and Gantayat, M. (2010). Growth trends in wind (1st ed.). Wind System Mag. Available at: http://www.windsys temsmag.com/article/detail/159/growth-trends-in-wind

Rigzone. (2016). How does a Tension Leg Platform (TLP) work?. Available at: http://www.rigzone.com/training/ insight.asp?insight_id=305

Safe, A. A., Kashem, S., Moniruzzaman, M. and Islam, M. T. (2014, October). Design, fabrication \& analysis of twisted blade vertical axis wind turbine (VAWT) and a simple alternator for VAWT. In 2014 9th International Forum on Strategic Technology (IFOST) (pp. 304-308). IEEE. https://doi.org/10.1109/IFOST.2014.6991127

Shabrin, N. and Kashem, S. B. A. (2017). A comprehensive cost benefit analysis of green building. Proceedings of International Conference on Recent Innovations in Engineering and Technology.

Shabrin, N., Khandaker, S. and Kashem, S. B. A. (2017). Investment and construction cost analysis on net-zero energy building technology. International Journal of Mechanical and Production Engineering, 5(4). 
Sheikh, M. I. B., Kashem, S. B. A. and Choudhury, T. (2017). February. Enhancing solar power generation using gravity and fresh water pipe. In IEEE International Conference on Mechatronics (ICM) (pp. 266-271). IEEE. https://doi.org/10.1109/ICMECH.2017.7921115

Siddique, M. B. M., Kashem, S. B. A. and Iqbal, A. (2018). Biofuels in Malaysian perspective: Debates and benefits. In IEEE 12th International Conference on Compatibility, Power Electronics and Power Engineering (CPE-POWERENG) (pp. 1-6). IEEE. https://doi.org/10.1109/CPE.2018.8372508

Siddique, M. B. M., Kashem, S. B. A. and Mathew, K. (2017). Home and water heating using biofuels. In Proceedings of International Conference on Recent Innovations in Engineering and Technology.

Tabassum, M., Haldar, M. K. and Khan, D. F. S. (2016). Implementation and performance evaluation of advance metering infrastructure for Borneo-Wide Power Grid. Frontiers in Energy, 14(3), 1-20. https://doi.org/10.1007/ s11708-016-0438-2

Tabassum, M., Kashem, S. B. A. and Mathew, K. (2018). Distributed energy generation-Is it the way of the future? In Advances in Power Systems and Energy Management (pp. 627-636). Springer, Singapore. https://doi.org/10.1007/ 978-981-10-4394-9 61

Tabassum, M., Kashem, S. B. A. and Siddique, M. B. M. (2017). Feasibility of using Photovoltaic (PV) technology to generate solar energy in Sarawak. International Conference on Computer and Drone Applications (IConDA) (pp. 11-16). IEEE. https://doi.org/10.1109/ICONDA.2017.8270391
Tay, F., Kashem, S. B. A. and Seng, W. C. Y. (2017). Automated miniature greenhouse. Advanced Science Letters, 23(6), 5309-5313. https://doi.org/10.1166/asl.2017.7365

Touati, F., Khandakar, A., Chowdhury, M. E., Antonio Jr, S., Sorino, C. K. and Benhmed, K. (2020). Photo-Voltaic (PV) monitoring system, performance analysis and power prediction models in Doha, Qatar. In Renewable energy. IntechOpen. https://doi.org/10.5772/intechopen.92632

turbinesinfo. (2011). Horizontal Air Wind Turbine - HAWT. Available at: http://www.turbinesinfo.com/horizontalaxis-wind-turbines-hawt

Wang, H. F. and Fan, Y. H. (2015). Performance calculation of floating wind turbine tension leg platform in the South China Sea. Journal of Engineering and Technological Sciences, 47(5), 568-588. https://doi.org/10.5614/j.eng. technol.sci.2015.47.5.8

WEF. (2016). What is Wind Energy?. Wind Energy Foundation. Available at: http://windenergyfoundation.org/what-iswind-energy

Wind Energy - The Facts. (2009). Offshore support structures. Available at: http://www.wind-energy-the-facts.org/ offshore-support-structures.html

Windpower Engineering. (2011). What types of metals are used in wind turbines?

World Wind Energy Association. (2014). Rotor and rotor blades: An overview. Available at: http://www.wwindea. org/technology/ch01/en/1_2_1_2.html 